\title{
Navigating Without Road Maps: The Early Business of Automobile Route Guide Publishing in the United States
}

\author{
John T. Bauer ${ }^{\mathrm{a}}$ \\ ${ }^{a}$ Department of Geography, University of Nebraska at Kearney, Kearney, Nebraska, USA; bauerjt@unk.edu
}

\begin{abstract}
In the United States, automobile route guides were important precursors to the road maps that Americans are familiar with today. Listing turn-by-turn directions between cities, they helped drivers navigate unmarked, local roads. This paper examines the early business of route guide publishing through the Official Automobile Blue Book series of guides. It focuses specifically on the expansion, contraction, and eventual decline of the Blue Book publishing empire and also the work of professional "pathfinders" that formed the company's data-gathering infrastructure. Be- ginning in 1901 with only one volume, the series steadily grew until 1920, when thirteen volumes were required to record thousands of routes throughout the country. Bankruptcy and corporate restructuring in 1921 forced the publishers to condense the guide into a four-volume set in 1922. Competition from emerging sheet maps, along with the nationwide standardization of highway numbers, pushed a switch to an atlas format in 1926. Blue Books, however, could not remain competitive and disappeared after 1937. "Pathfinders" were employed by the publishers and equipped with reliable automobiles. Soon they developed a shorthand notation system for recording field notes and efficiently incorporating them into the development workflow. Although pathfinders did not call themselves cartographers, they were geographical data field collectors and considered their work to be an "art and a science," much the same as modern-day cartographers. The paper concludes with some comments about the place of route guides in the history of American commercial cartography and draws some parallels between "pathfinders" and the digital road mappers of today.
\end{abstract}

Keywords: Route guide, Automobile Blue Book, Road map

\section{Introduction}

At the dawn of the twentieth century it was difficult to travel long distances in an automobile because maps appropriate for this new form of transportation were scarce. The locally based mental map that people acquired through experience served well for navigating with horse and buggy. When someone wanted to travel farther than a day's carriage ride, they boarded a passenger train and the railroad navigated for them. But with an automobile, people had the ability to travel long distances on their own, without railroads. Their mental map, though, was insufficient for navigating areas far from home. So without road maps, how did automobile drivers know what roads to take? What directions did they travel? Where did they turn?

An early solution to this navigation problem were automobile route guides. Listing turn-by-turn directions between cities, they allowed early drivers to navigate networks of unmarked, local roads. Thus, in the United States, automobile route guides were important precursors to the road maps that Americans are familiar with today (Bauer 2009). Few researchers have analyzed their roles in the history of cartography. Although many route guides were marketed during the first decades of the century, the Official Automobile Blue Book series was by far the most widely used and successful. It remained in publication for nearly forty years and was one of only two guide series to cover the entire United States.
This paper examines the early business of route guide publishing by examining the expansion, contraction, and eventual decline of the Blue Book publishing empire as well as the work of professional "pathfinders" that formed the company's data-gathering infrastructure. Primary sources include forty-four volumes of the guide published between 1901 and 1937, period newspaper stories, technical articles from early automobile trade magazines, and United States court records.

\section{The Official Automobile Blue Book}

The Official Automobile Blue Book was published as a multivolume series from 1901 until at least 1937. In Blue Books, geographical information was not recorded and transmitted in a cartographic format, but rather in a textual format, written as turn-by-turn directions. Single volumes in the series often contained over 500 separate routes, re- quiring 600 pages or more of description. Because of the textual format, each physical route had to be described twice, once in each direction. The forward and reverse versions of each route consisted of the same landmarks and turns, only the directions were reversed.

Even though users navigated with the written directions, simplistic maps were still included in the books. Highly generalized maps served as indexes to the routes and supplements in urban areas. Each route segment was labeled with an identification number which referred the user to the associated text about that segment. Supplemental maps of major urban areas helped travelers follow routes through cities and showed connecting 
routes to other destinations. Routes began and ended at major road intersections in the central business district, typically adjacent to the county courthouse, railroad depot, or other prominent landmark.

Figure 1 shows an index map, urban map, and route directions from the 1910 Middle West volume 4. Route 51 connects Bloomington, Illinois with Chicago, Illinois and is 148.4 miles $(238.8 \mathrm{~km})$ long. The entire route comprises sixty-five individual segments and requires almost four pages of text to describe. A brief description of the road conditions appears at the beginning.

Central to the guide's wayfinding narrative is the use of total and intermediate distances. The distance, in miles, of each turn in the directions from the beginning of the route, plus the distance from the previous turn, is listed along the left-hand side of the route log. Users reset their odometers to zero or kept a pencil and paper handy so they could keep track of distances and intermediate mileages.

In addition to distances, landmarks are also at the heart of the route guide's narrative. Not only did prominent landmarks identify the beginning and end of routes, they identified individual turns or segments along the route. Most commonly these intermediate landmarks were railroad tracks and power/telephone poles. For example, Route 51 references railroad tracks thirty-three times within its sixty-five segments. Other common landmarks were buildings, bridges, businesses, trolley tracks, and parks, including fairgrounds and cemeteries. Compass directions were rarely used in any of the route segments.

This reliance on written directions with mileages, landmarks, and turns made navigation with the Blue Books difficult and was cited by map historian James Akerman as the route guide's chief flaw (1993). Without detailed maps keyed to markings on the ground, routes needed to be flawless and tourists had to follow them precisely. It is easy to envision any number of scenarios where a tourist finds themselves off the route. In these situations they would have to retrace their path until they encountered a familiar place earlier on the route or search out an alternative.

\subsection{C.H. Gillette and the Class Journal Years}

The Official Automobile Blue Book was founded by Charles Howard Gillette, a prominent businessman from Hart- ford, Connecticut (Hart 1919). In 1901 he incorporated the Official Automobile Blue Book Company in Newark, New Jersey with $\$ 3,000$ of capital (The Horseless Age 1901). Gillette's 1901 Blue Book covered the Boston, New York, Philadelphia, Washington, and Baltimore metropolitan areas. Its stated purpose was to promote touring by establishing routes that connected automobile "supply stations." The Blue Book placed stations into four categories according to the services they provided.

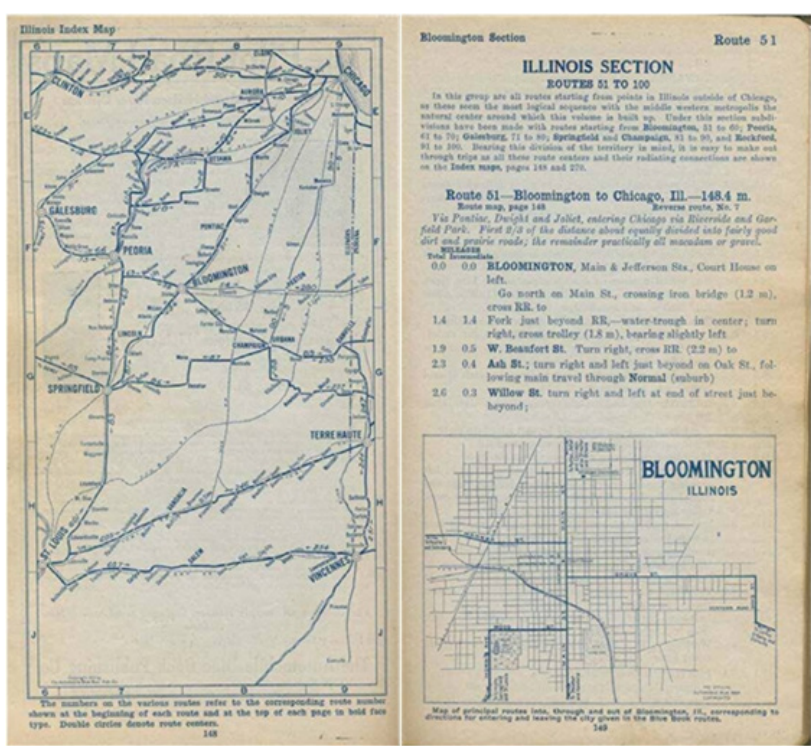

Fig. 1. Route index map, urban map, and beginning of Route 51. (Source: Official Automobile Blue Book, Vol. 4 The Middle West, 1910, p. 148-149.)

Sixty-two routes were included in the 1901 edition. Each route consisted of a short descriptive paragraph along with a table showing information about supply stations. Towns were linked together in such a way as to ensure that supply stations would be found every ten to fifteen miles (sixteen to twenty-four kilometers). The distance between each station, along with the surface material and condition of the roads, was also indicated in the guide. Motorists were supposed to navigate using a detailed description with few intermediate distances.

Between 1903 and 1905, Gillette failed to pay business taxes to the state of New Jersey and in 1906 his corporate charter was revoked and he lost the company (Trenton Times 1906). Its assets, including the Blue Book, were purchased by The Class Journal Company, a large New York City publishing house specializing in automobile and technology themed magazines.

Under Class Journal, the Blue Book underwent three important changes. First, Class Journal hired Robert Bruce, famous Good Roads advocate, as Editor and Anton L. Westgard, famous pathfinder of the American West, as cartographer. Under Bruce's leadership the publication was completely redesigned and refocused, further commercializing automobile touring and navigation. The publisher's forward to the 1906 volume announced these changes as "an entirely new style of map-making." The 1906 book placed more emphasis on touring, and less on operations and maintenance, reflecting the increase in automobile ownership and touring. Gone were the detailed information about supply stations. In its place were full-page picture advertisements for garages, hotels, automobile manufacturers, and other related businesses. Route index maps, included for the first time in 1906, along with strip maps and large-scale maps of cities and towns were also added to aid tourists. Second, the 1906 guide received sponsorship by the American Automobile Association (AAA), immediately boosting its popularity. The AAA 
placed its logo on the front cover and advertised itself prominently throughout the volumes' pages. Blue Books were offered to association members at a reduced price. Third, in 1907, the territory covered by the guide was expanded to include the southern states and this required increasing the series from one volume to three.

\subsection{The Automobile Blue Book Publishing Co. Years}

In June, 1909, The Class Journal Company spun off the Blue Books, reorganizing them into a new company called the Automobile Blue Book Publishing Company. Norton Van Sicklen, an inventor of an early speedometer, was named President and Robert Bruce continued as Editor. The new company quickly went after the industry competition. In August, 1909, they purchased the entire business of F.S. Blanchard Company, of Worchester, Massachusetts, includ- ing its Red Book publication. The Red Book was a similar route guide available for the New England states. Henry McNair, routefinder for the Red Book joined the Blue Book staff in New England (The Automobile 1909a). Under this new leadership, the Blue Book's scope and influence expanded rapidly. In 1909 , 25,000 books were sold and Class Journal hoped to double that figure the next year (The Automobile 1909b). The 1910s were a decade of consistent growth for the Blue Book. During the next ten years, no other route guide matched its territorial coverage, route density, or popularity. The series steadily grew as more routes and territory were added. After expanding to three volumes in 1907, a fourth was added in 1909 and a fifth in 1912. In 1913, a sixth volume was added, completing coverage for the entire United States. At this time, the Blue Book was the only route guide that could take a motorist on a transcontinental journey, from coast to coast. Year after year, the size and coverage of the series grew until it reached its peak in 1920 with thirteen volumes (Table 1).

\begin{tabular}{|c|c|c|c|}
\hline Year & Series Size & Volume Names & Price \\
\hline $1901-1906$ & 1 volume & The Northeast & Unknown \\
\hline 1907 & 3 volumes & $\begin{array}{l}\text { Volume } 1 \text { - New York \& Canada } \\
\text { Volume } 2 \text { - New England } \\
\text { Volume } 3 \text { - N.J., Pa., \& The South }\end{array}$ & $\$ 2.50$ \\
\hline $1908-1911$ & 4 volumes & $\begin{array}{l}\text { Volume } 1 \text { - New England } \\
\text { Volume } 2 \text { - New York } \\
\text { Volume } 3 \text { - N.J., Pa., \& The South } \\
\text { Volume } 4 \text { - Middle West \& Chicago }\end{array}$ & $\$ 2.50$ \\
\hline 1912 & 5 volumes & $\begin{array}{l}\text { Volume } 1 \text { - New York \& Canada } \\
\text { Volume } 2 \text { - New England \& Eastern Canada } \\
\text { Volume } 3 \text { - N.J., Pa., \& South Atlantic States } \\
\text { Volume } 4 \text { - Middle West } \\
\text { Volume } 5 \text { - Mississippi River to Pacific Coast }\end{array}$ & $\$ 2.50$ \\
\hline 1913 & 6 volumes & $\begin{array}{l}\text { Volume } 1 \text { - New York \& Canada } \\
\text { Volume } 2 \text { - New England \& Eastern Canada } \\
\text { Volume } 3 \text { - N.J., Pa., \& The South } \\
\text { Volume } 4 \text { - Middle West } \\
\text { Volume } 5 \text { - Missigsippi River to Pacific Coast } \\
\text { Volume } 6 \text { - Pacific Coast }\end{array}$ & $\$ 2.50$ \\
\hline 1914 & 5 volumes & $\begin{array}{l}\text { Volume } 1 \text { - New York \& Canada } \\
\text { Volume } 2 \text { - New England \& Eastern Canada } \\
\text { Volume } 3 \text { - N.J., Pa., \& The South } \\
\text { Volume } 4 \text { - Middle West } \\
\text { Volume } 5 \text { - Mississippi River to Pacific Coast }\end{array}$ & $\$ 2.50$ \\
\hline
\end{tabular}

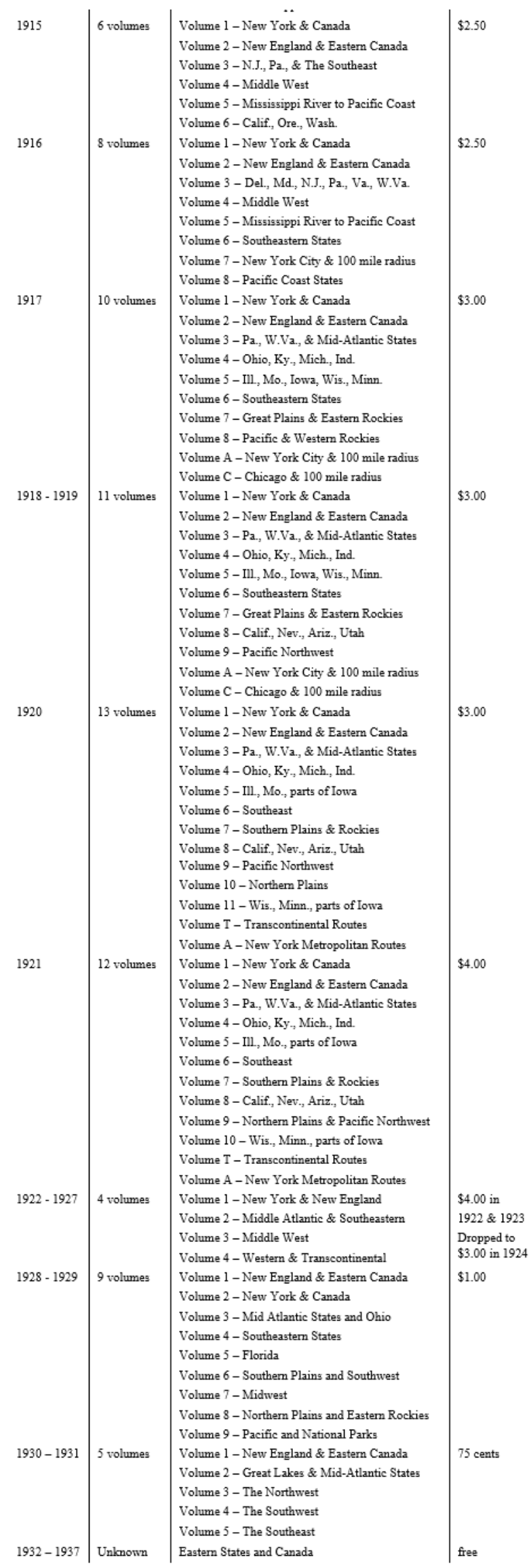

Table 1. Territorial coverage, size, and price of the Official Automobile Blue Book series 


\subsection{Bankruptcy and Automobile Blue Books, Inc.}

The short economic recession that followed the end of World War I impacted the automobile industry hard and the Automobile Blue Book Publishing Company was not immune to its effects. Apparently, a business model that included a thirteen-volume series, and the work that went into maintaining it, proved too costly and unsustainable. In 1920, the Company filed for bankruptcy in the United States District Court of Southern New York and was placed into receivership. Court documents show the company had $\$ 572,000$ in assets, but $\$ 625,000$ in liabilities and $\$ 1,170,000$ of debt. While in receivership, the Company reduced the size of the 1921 series by one volume, to twelve total, and increased the price of the volumes from $\$ 3$ to $\$ 4$ each (Table 1). The company emerged from bankruptcy in late 1921 reorganized as Automobile Blue Books, Incorporated.

Automobile Blue Books, Inc. may have been leaner, but its guides indicate a company in decline. In 1922, the entire series was condensed into four volumes in a clear attempt to reduce costs. This was achieved by consolidating volumes, cutting routes, and abbreviating the route directions. For example, Volumes 7, 8, and 9 from 1921 were combined to create Volume 4 for 1922. Routes were removed and those that remained were printed in a smaller amount of space. The 1921 Volume 7 lists forty-eight routes (including reverse routes) in Nebraska. In 1924, only twenty of them remain. The 1924 Volume 4 used a smaller font, two-column pages, abbreviated and omitted common words such as "turn" and "corner," and omitted intermediate mileages so it could squeeze over 1,500 routes into 793 pages. The price of each volume remained $\$ 4$ in 1922 and 1923, but was reduced back to $\$ 3$ in 1924 , probably in response to declining sales (Table 1).

Still more drastic changes were to come. In 1926, the AAA stopped distributing Blue Books and launched its own series of guide books to replace them. Without its privileged relationship with the AAA, sales fell. Blue Book publish- ers attempted in 1928 to make the series more competitive by switching to a nine volume atlas format. All turn-by- turn directions were removed and replaced with large-scale highway maps, greatly reducing the number of pages in each volume. The price of each was even reduced from $\$ 3$ to $\$ 1$. This radical change, however, could not stem the sales decline. In 1930, publishers redesigned the series once again, this time as a tall, slim, guidebook with a large, accordion-style foldout map. Five volumes were offered and priced at 75 cents each. A final redesign was done in 1932, this time as a double-folded saddle-stapled brochure. The largescale highway maps were reduced and an even greater emphasis was placed on tourist destinations and services. The brochures were distributed for free and it is unknown how many volumes were in the series. These changes were ultimately not enough to save the series and it ceased publication after 1937 (Table 1).

\section{Pathfinders}

Blue Book route directions were compiled by pathfinders. Pathfinders were early automobilists who field-compiled routes while traveling local, unmarked, roads. Although they did not call themselves cartographers, they were geo- graphical data field collectors and considered their work to be an "art and a science," much the same as modern-day cartographers. The Class Journal Company relied on information provided by pathfinders and auto club members. The compiler's forward to a 1907 Blue Book acknowledges "the friendly cooperation received from the American Auto- mobile Association, its affiliated and other clubs, and from tourists who have placed notes of their own trips" (Class Journal Co. 1907, xxxv).

Some pathfinders were successful enough to parlay their skills into full-time employment. Perhaps the most famous and successful professional pathfinder was Anton L. Westgard, who was employed as Field Representative and official pathfinder for the AAA. Westgard was born in Norway, in 1865, and immigrated to the United States at age eighteen. He began his pathfinding career in 1903, after purchasing his first automobile, and in just a few years earned the reputation as a foremost authority on automobile routes and touring. According to his memoirs, Tales of a Pathfinder, he was instrumental in establishing nearly forty trans-continental routes, including the Lincoln Highway (1920). The Class Journal Company hired Westgard in 1906 as official cartographer and he is credited in the 1907 Volume 1 as such. His maps even contain his initials (ALW). Westgard continued as cartographer until the Automobile Blue Book Publishing Company was formed in 1909 and apparently did not join the new company.

In addition to relying on amateur pathfinders from automobile clubs, by 1907 the Blue Book publishers were employing their own professional pathfinders and outfitting them with official cars. The 1907 guide states that "between eight and nine thousand miles of the routes described anew for 1907 have been covered personally, either by the Blue Book car, or by our staff in cooperation with local autoists" (Class Journal Co 1907, xxxiii). One such professional Blue Book pathfinder was John P. Dods. Dods was born in 1883, in Fredonia NY. In 1908, he graduated from Cornell University with a degree in mechanical engineering. Later that year he was hired in the editorial department of The Automobile, a trade journal owned by Class Journal. When the Automobile Blue Book Publishing Company was formed in 1909 he was appointed "Western Manager" and spent the next ten years with the company.

Each official Blue Book car was operated by a two-man team, consisting of a driver and "route compiler," whose job was to mark mileages, turns, and landmarks. A 1910 Chicago Daily Tribune article described these workers as "geography makers [or] professional route finders, who scour the country in their machines mapping out fresh trails for automobile tourists who wish to take long runs 
through sections of the country unfamiliar to them" (Chicago Daily Tribune 1910).

In 1911, Dods published an article in Motor Age in which he explained in detail the methods he developed for recording field notes and efficiently incorporating them into the route development workflow (Dods 1911). At first, he explains, route data was recorded as long-hand directions. This process proved inadequate, especially as the speed of the pathfinding cars increased and in areas where the landscape was complex. Also, it was difficult to write a reverse route from longhand directions. The Blue Book pathfinders, therefore, devised a method of shorthand sketching. Dods explained that the sketch saved time and provided data from which a route could be written in both directions. Figure 2 is an example sketch map from Dods's article. According to Dods, the sketch and its symbols standardized the route information and simplified interpretation. He writes, "Even a stranger who never covered a mile of the route could take one of these sketches and knowing the symbols could read it now or a year hence" (Dods 1911, 4). One wonders why the Blue Book publishing company went through the added effort of compiling written directions then, instead of just publishing the sketches, but that is a future topic.

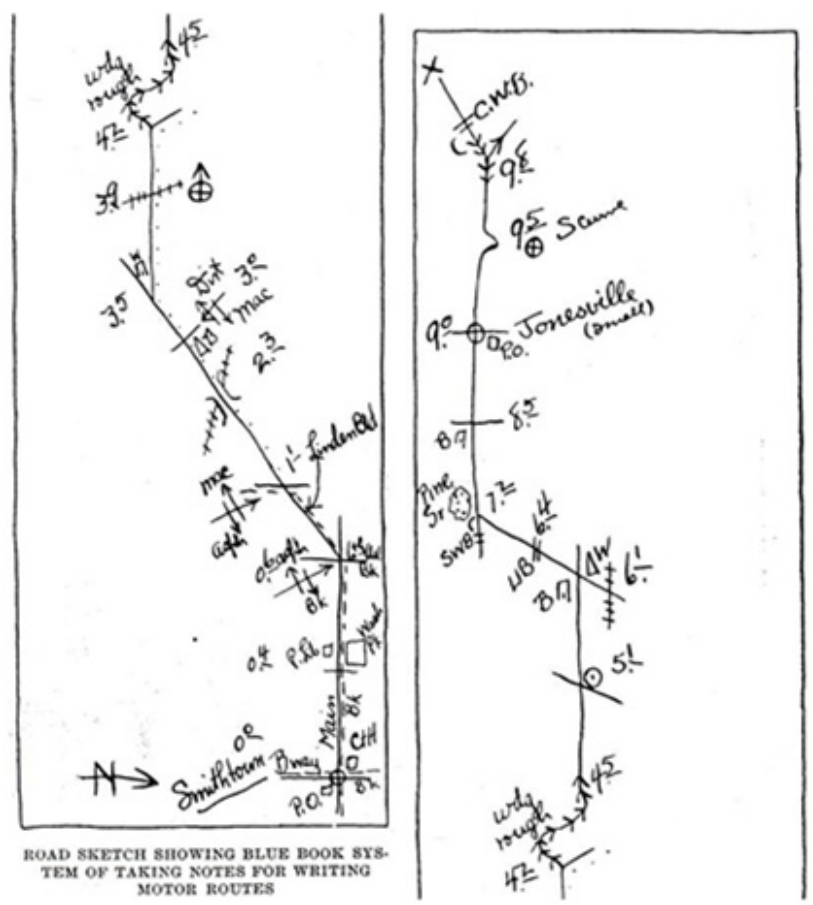

Fig. 2. Example pathfinder sketch map. (Source: Dods, 1911.)

Working from spring to late fall, each team spent the entire driving season covering thousands of miles as they created new routes and updated others in their assigned region of the United States. Robert Bruce and John F. Mixer, for instance, assigned to New York state, drove over 10,000 miles $(16,093 \mathrm{~km})$ in 1909. E. R. Mixer and Henry MacNair, responsible for all New England, covered 11,000 miles (17,702 km). John P. Dods and Fred G. Lee, responsible for the Middle West, covered over 10,000 miles $(16,093 \mathrm{~km})$ that season (The Automobile 1910).
The work was slow, especially by modern standards. Before developing new routes, teams explored alternate roads so they could find those with the shortest distance or most scenic value. A typical crew covered an average of 15 miles $(24 \mathrm{~km})$ an hour. Crews were considered highly efficient if they covered 150 miles $(241 \mathrm{~km})$ in a day, but because of interruptions and bad weather, an average week only produced 300 miles $(482 \mathrm{~km})$ of new route. After field-compiling their notes while on the road, crews mailed them back to the New York City or Chicago offices where they awaited the crew members return at the end of the driving season. Field crew members were responsible for writing their own turn-byturn directions from the sketches, although draftsmen and cartographers compiled the guide's maps. The cost of this routefinding work was high. Publishers spent almost $\$ 1,000$ per month on each team, including $\$ 600$ for the salaries of the driver and route compiler (Chicago Daily Tribune 1910). These figures do not include the production costs associated with drafting the maps and assembling the turn-by-turn directions, or the costs of publication.

\section{Reasons for the rise and fall of the Automobile Blue Book}

Blue Books were uniquely suited for navigating the primitive network of local roads that existed prior to the 1920s. Today, the methods of navigating by detailed mileages and turn-by-turn directions appear cumbersome and unnecessary to some drivers, especially those who excel at map reading, but they were ideally suited for the conditions of automobile travel during the first two decades of the twentieth century. Roads at the time were constructed with only local uses in mind and often lacked descriptive signage. Prior to the automobile, roads that stretched across the country, or even a state, in an unbroken fashion were unnecessary. Travel that far was reserved for railroads. Therefore, anyone wishing to travel cross-country by automobile was forced to make hundreds of turns onto hundreds of different roads. Such detail could not be depicted at an appropriate scale on a sheet map because of the generalization that would be required. Publishers and automobile enthusiasts turned to route guides such as the Automobile Blue Book and their turn-by-turn directions as a more effective solution. As automobile touring increased in popularity during the 1910s, so did the Automobile Blue Book because it was the ideal navigating companion.

By the mid-1920s, though, the popularity of Blue Books began to wane because of competition from emerging sheet maps. Motorists could obtain maps for little or no cost, so it became increasingly difficult for them to justify the high cost of a Blue Book set. In 1926, the American Association of State Highway Officials (AASHO) devised a unified highway identification plan based on one and two-digit numbers (Weingroff 1997). States quickly adopted this plan, which ensured that all interstate routes maintained the same numeric designations from start to finish. Combined with improvements to the highway system that built new roads 
as continuous, unbroken networks, these two innovations eliminated the need to show, in detail, every individual turn. Thus sheet maps could effectively depict a generalized route at an appropriate scale. The Official Automobile Blue Book series fell out of favor during the late 1920s because improvements to the road network and a uniform highway identification system made their solution to the navigational problem obsolete and allowed sheet maps to take their place.

\section{The commercial legacy of the Automobile Blue Book}

The Official Automobile Blue Books introduced commercialization to automobile touring and the business of road mapping. Automobile Blue Books encouraged and promoted automobile touring and users were expected to patronize the businesses that advertised in the series. Each volume contained hundreds of advertisements for automobile-related literature, hotels, resorts, garages, auto dealers, and other related businesses. Some even displayed signs advertising themselves as "Official Automobile Blue Book Garage" or "Official Automobile Blue Book Hotel." It is unknown whether these businesses paid a premium advertising fee for the endorsement, or if the distinction was granted on their own merit. Regardless, it is clear that tourists were expected to patronize the businesses that advertised in the guides. Popular touring destinations also advertised, often purchasing large, multiple-page, color advertisements that were intended to increase touring interest. For example, in the middle of the 1921 Volume 7, which covers the southern Plains and Rocky Mountain states, is a fullcolor, twenty-four page "National Touring Objectives" insert. This special section advertises destinations throughout the United States, including New England, New York, North Carolina, Michigan, Colorado, Montana, and Oregon. Since route directions to some of these destinations are covered in other Blue Book volumes, these advertisements also prompted users to purchase additional volumes in the series.

This pattern of commercialization was followed years later by the ubiquitous "oil company" road maps (Akerman 2006, 2002, 1993; Ristow 1964, 1946; Schmiedeler and Perucca, 1996) and the official state highway maps that be- came commonplace after them (Akerman and Block, 2005). "Oil company" maps were intended to foster brand loyalty to the issuing oil company, thus selling more petroleum products. Companies gave away free maps in hopes that tourists would return again and again to their branded service stations. Official state highways maps were also intended to be tools of economic development. They advertised touring destinations, thus encouraging tourists to spend their time, and money, within the issuing state.

Today, the commercial legacy of Automobile Blue Books is continued by the Tour Book series from the AAA and the many websites, maps, and glossy tourist guides produced by state departments of tourism. Even the cumbersome turn-by-turn navigation method used in the Blue Books has returned with a modern counterpart.
Websites such as Google Maps, and in-car GPS navigation units provide maps and turn-by-turn directions with the click of a mouse or push of a button. It is a bit ironic that turn-by-turn directions, the navigation method abandoned by the Automobile Blue Book in 1928, are widely available today and seem to be gaining in popularity. In many ways, even though Blue Books have been gone for 80 years, they are still with us today.

\section{Acknowledgements}

I would like to thank the late David L. Cole, of Santa Maria, California, for opening to me his private collection of automobile route guides for research. I also wish to thank the Research Services Council of the University of Nebraska at Kearney for providing grant funding to visit Mr. Cole's collection.

\section{References}

Akerman, J.R. (1993). Selling maps, selling highways: Rand McNally's 'Blazed Trails' program. Imago Mundi, 45, 77-89.

Akerman, J.R. (2002). American promotional road mapping in the twentieth century. Cartography and Geographic Information Science, 29(3), 175-191.

Akerman, J.R. (2006). Twentieth-century American road maps and the making of a national motorized space, in J.R. Akerman (Ed.)

Cartographies of Travel and Navigation, (151-206). Chicago: The University of Chicago Press.

Akerman, J.R. \& Block, D. (2005). The shifting agendas of Midwestern official state highway maps. Michigan Historical Review, 31(1), 123-165.

Automobile, The. (1909a). Blue Book absorbs N.E. Red Book. The Automobile, Aug 5, 244. Automobile, The (1909b). Blue Book sales three miles long. The Automobile, Dec 9, 991. Automobile, The. (1910). Official Automobile Blue Book work. The Automobile, Feb 10, 313.

Automobile, The. (1912). Road-map and route-making: once haphazard, now art. The Automobile, 26(21), 1155-1158.

Bauer, J.T. (2009). The Official Automobile Blue Book: Precursor to the American Road Map. Cartographic Perspectives, 62, 4-27. Class Journal Company. (1907). New York and Canada, Vol. 1 of The Official Automobile Blue Book of 1907. New York: The Class

Journal Company.

Chicago Daily Tribune. (1910). Motor Car Scouts Make New Map. Feb 6, H4. Dods, J.P. (1911). Advancement in the Art of Pathfinding. Motor Age, 20(6), 1-6.

Hart, S. (1919). Gillette, Charles Howard, founder of Automobile Blue Book, in S. Hart (Ed.) Encyclopedia of Connecticut Biography, Genealogical-Memorial, Representative Citizens Vol. 9, (225-228). Boston: American Historical Society.

Horseless Age, The. (1901). Automobile Blue Book. The Horseless Age, July 3, 313. 
Ristow, W.R. (1946). American road maps and guides. The Scientific Monthly, 62(5), 397-406. Ristow, W.R. (1964). A half-century of oil-company road maps. Surveying and Mapping, 24, 617-637.

Schmiedeler, T. \& Perucca, K. (1996). Motor trails are calling!: Travel, tourism and commercialization in the cover art of Indiana Standard's road maps. The Great Lakes Geographer, 3(1), 69-87.

Trenton Times. (1906). Proclamation, State of New Jersey. Trenton Times, Feb 15, 8. Westgard, A.L. (1920). Tales of a Pathfinder. Washington, DC: Andrew B. Graham Co.

Weingroff, R.F. (1997). From names to numbers: The origins of the U.S. numbered highway system. AASHTO Quarterly, 76, 6-15. 